\title{
Identifying and Studying the Role of Women in Ancient Persia
}

\author{
Mehrdad Afshoun
}

\begin{abstract}
Woman is a creature who is decorated with mysteries and filled with amazement. The world of human beings continue in the shade of this creature.Doubtlessly social condition of woman is no separate from it's general condition of that society in no historical periods.Human beings is such as myth that has special believes during the history. This reality make cultural codes of that people known to us. Woman is one of these myth that has a lot of importance in ancient times Iran. A lot of changes happen in some periods maybe 10000 years before $\mathrm{BC}$ (before christ) in climatic conditions and a cave man make house for himself or herself little by little . Family was central power of this tribe in this period,because woman works in house also out of house with man in production to remove human needs. To reproduce babies and reproduction was woman's natural duties and responsibilities. So woman has more importance than man in fact the role of woman was to connect families with each other in every where. Woman is a basic factor in power creation Woman is abasic factor in power creationThe subject of this research is to study the role of woman in ancient times Iran to show us the role and place of woman in society, and different ideas and believes that we have about womans.
\end{abstract}

Keywords-woman, Iran, ancient.

\section{INTRODUCTION}

Woman is one of GOD's creature. One half of this universe consist of woman .Womans exist because of world existing. GOD created woman when he created human beings. Womans have different roles during history and have eminent place for themselves. Our ancestors put beautiful names for their womans and to attack importance for them, they celebrate the Esfandigan celebration infifth of Esfand.They called this day, the woman's day. They bring presents for woman in this day (woman's day). Woman sit on kings bed in this day .They can work and have social activities. They can works outside of hose too and they can choose their husbands and they were free in their husbands selection. Avestan attack so much importance for woman. Ancient man even praise honest woman in their prayers. If they remember man's goodness and put good virtues for man beside of this they put good virtues for woman. They attack rights and laws for woman in ancient times for example woman has right of heritage in ancient Ilam. Woman works outside of house in Hakhamaneshi period. They recceive wages such as man. Even woman who work and were pregnant, they have this right to leave their work and they receive wages too whenthey were in the state of having been dismissed. Islam doesn't appear in ancient times but woman

Mehrdad Afshoun, Department of Islamic Science, Ahvaz Branch, Islamic Azad University,Ahvaz, Iran. had the Islamic dress code and we had this condition in Ilamie periods. Our ancestors attack importance for everything in this universe from water, earth, soil, animal, vegetables to human body. They attack important for human body for example showing importance of putting shoes and wearing dress for man and woman. We can see the documents of ancient times woman in a bas-relief carved on a rock face in TakhteJamshid. To underestand how much our ancestors attack importance for their woman. They known the veil as a shame and bashfulness. The role and appearance of woman had a high lands and low lands in Iran. Always they attack importance to equality of man and woman. Our myths attitude and historical view are stories from eminent and famous personality.Persian woman had eminent status, because man and woman had equality rank in zortosht periods and woman could reach to judgment and kingdom rank. Some of the great woman in ancient time are:

Yootab:Iranian woman warlord waz the sister of Ariobarzan famous warlord of Dariush kingdom armed forces. They remember she as a Atropatan king from 20 years before BC to 20 years after BC. She died because of her patriotism and people remember her as a good personality

Artemiz:The first and only sailor woman who reach to navigation rank in khashayar kingdom armed forces in 480 years before $\mathrm{BC}$ and she guided kingdom armed force from marine borders between Iran and greek wars. Historians called her the most beautiful, outstanding and calmness woman of that period . another form of her name is Artemis.

Atoosa: she is the princess of more than 28 Asian countries in Dariush kingdom times. Herodot, the father of history remember she as a Dariush great queen. And he says thatAtoosa was an intellectual friend and spiritual supporter for Dariush in wars.Herodot says that Atoosa commanded to some important historical Iranian wars.

Artadokht:shewaz treasury and financial affairs minister of Iran government in forthArdowan kingdom . According to Ashkanian book by Russian Diankonof , a great orientalist, she systematized taxes and she doesn't commit a crime in financial affairs and she flourished partian economy kingdom.

Azarmidokht:She was Iranian woman princess in( A.D.).63). She was KhosroParviz girl. Khosroparviz was the king of some Asian kingdom countries after Gashtasebbande. Azarmidokht was thirteenth two of Sasani kingdom. The meaning of this name is Cham. It means always young.

Azarnahid: she was the best princess of Iran princess in Shahpoor kingdom. We can see the name of this great princess and her governmental affairs in Iran borders on Kaabazartosht inscription in Fars province. They praise her deed. 
Zarbanoo: She was Iranian fighter warlord. Rostam's girl and banoogashesb's sister. She was a good horse woman. She showed much brave in wars. History called her as a brave fighter who releaseZal, Azarbarzin and Takhvar from prison.

Farokhroo:She was the first minister woman in Iranian history. She reaches to kingdom Iranian minister rank.

Kasandan: She was the first powerful personality after Iranian kingdom. Kasandan as a princess of 28 Asian countries govern the country beside her husband, great Korosh. Greek historian remember her good deedsand her magnanimity. Resources says about woman place in Zartosht times. Such as following:

Woman had high and excellent place in Zartosht prophet times. And they had freedom to socialize with people, they had property such as ground and houses. They could investigate their husbands affairs or they could become their lawyer. Woman 's place decrease in value specially between rich people after Daryush. Poor woman socialize among people because of working, so they maintain their freedom. We should confess that this speechby Wildorant about woman place in Achaemenian times is unfairly judgment in association with other sources. They train military laws to Persian girls such as boys. And they play physical sports. According to Beryan 1379:605 they remember horsewoman rider beside princess in DaryushAchaemenian times. Fighter woman is one part of Iranian colloquial traditions. So, we can result: According to Beryan( 1379:605).

\section{REVIEW OF LITERATURE}

\section{WOMAN IN "SHAHNAMEH"}

All of the knowledgeable people from ancient time cultures and old persian literature known well that Ferdousi is the only person in Shahnameh(a great and long poem) who describes woman as a good friend for man and a person who is speaking the same language as man.Ferdousi describes woman in the best and beautiful and eloquent way. Some Shahnameh'famous woman such as Faranak,Roodabeh,Sindokht, Tahmineh and soon. They are good example of beauty, wisely and masculinity and modesty.Woman are husband's friend and they are in the battle field when there is necessity.Faranak were in the battle field against Zahak after her husband death. Gerdafarid fight with Sohrab when Iranian fighters were afraid of him. Jarireh set fire to all of the fortress after Siavash failure, she killed all of the greyhound horses and commited suicide to save herself from enemy. Katayoon stayed beside her boy kindly and wisely until the end. She fight with Gashtaseb because of his despotism and villainous deeds. Sindokht was Roodabeh's mother and Mehrab's wife. She was the most wisely woman in that times, she was resistant and patient in domestic and political living disasters. Also she was a good fighter in battlefields. ( According to Islamic Nedoshan 1370, P 20). Woman in Shahnameh are loyal to Iranian ancient stories. They have ancient great pride. If they commit a sin, they are not weak., but they are hard and powerful. They have dauntless innovation and championship loyality. They fight with their husband and they are in all of the fights.

\section{WOMAN Right In ANCIENT TIMES IRAN:}

Woman are active for providing facilities for better living from the first day of human being living. Man and woman live with each other. It is not worthy to separate manfrom woman or to have an advantage for man or woman. We read in valid historical documents and Avestan that woman are man's escort and helpful. Her main duty in family was to deal with housewife and domestic affairs. According to Balsar'introduction book (MaticalHezarDastan), Balsar writes: they divided the sovereign of family affairs between man or house chief and woman or housewife. According to (RostamShahrzadi 1386 p 5) hosewife has more capacity to deal with domestic affairs and she has more freedom and man couldn't interfere in her affairs. Woman's roles in house are not comparable with man's roles. Their authority are not against each other. One of them complete another one .If man is the real lord of hose, his wife is house minister . she deal with all the affairs in house in fact if woman is an autonomous person, she could change herself to social beings, because of her domestic house affairs. Her duties are related to dealing with domestic affairs such as bringing water, cooking food for man , field workers and waiters providing fodder for animals and house birds . woman did same affairs in fields. That it's limitation depends on year's season, economic organizational skills, crop type and the number of workers. When one woman went outside of house she accompanied other womans and she did other affairs such as house and domestic affairs which were not feasible in houses. For example cooking bread in wood-fired (According to Segaltan, Elyasi Translation 1380 P 233).

\section{THE Right Of Womab's OWNERSHIP IN ANCIENT TIMES IRAN}

Law supports woman against man to have rights in her husband financial wealth.To stipulate this law as a condition. Woman's share from her father property which she carry with herself to her husband house and some property which were her trousseau, they were hers until she was alive and only her husband has this right to use them. And if a woman die and she doesn't have any child, they returned back her trousseau to her father house ( YarShater and some other man, 1377, P 35). According to law woman has no right to act cruelly against her husband and children. When one man attributes one title such as fornication to his wife while they have child, he shouldn't refrain from paying living expenditure to his wife and child until he could prove her indecent behavior.But he could refrain from paying living expenditure to his wife after proving this reality ( RostamShahrzadi, 1386, P 112).

\section{V.RESULT AND CONCLUSION}

As we say in following paragraph one half of the society consist of womans.They have some main roles in social structural. They do many affairs in society. They have many spiritual or material values. But unfortunatly society turnsa blind eye on them and imposes some difficulties on them . women should have knowledge about their roles and place in society.They should grow and improve with society's growing. Specially today's woman of our country should know that our 
ancient ancestors respected woman so much even in that times and periods which they had not any civilization. Iran were that place where woman could reach to warlord, minister and kingdom ranks. Also they have equal legal and laws.

\section{REFERENCES}

[1] HedaayatallahAlavi, "Woman in ancient Iran", Tehran, Hirmand, 1377.

[2] Jalil Dost khah, "Avestan", The oldest Iranian poetry", Tehran, Morvarid, 1374.

[3] Eynabi, Mehrasa,“ eight thousand years of Iranian people cloth history", Hiromand publishers, first edition, 1385.

[4] R.Garshiman, "Iran from the beginning to Islam" Translated by Dr. MohamadaminMoin, Translation and book publishing institute, Fourth edition, Tehran 1355.

[5] Lahiji, Shahla, Mehrangiz, “ Recognizing Iranian woman's identification in history and pre history", Third edition, Roshangaran publishing and Woman research, 1381

[6] Shater Maria," Iran country dress", Translated by PeymanMatin, Iranicaseries, Amirkabir publisher, 1382.

[7] Mari Kokh," Haidy", Translated by ParvizRajabi, Told by Daryush, fourth edition, Tehran, 1377

[8] Mel Jol" FerdousiShahnameh" Sakko edition. 